\title{
Impact of two different types of El Niño events on runoff over the conterminous United States
}

\author{
T. Tang ${ }^{1}$, W. Li ${ }^{1}$, and G. Sun ${ }^{2}$ \\ ${ }^{1}$ Earth and Ocean Sciences, Nicholas School of Environment, Duke University, Durham, NC 27708, USA \\ ${ }^{2}$ Eastern Forest Environmental Threat Assessment Center, Southern Research Station, United States Department of \\ Agriculture, Forest Service, Raleigh, NC 27606, USA \\ Correspondence to: W. Li (wenhong.li@duke.edu)
}

Received: 28 June 2015 - Published in Hydrol. Earth Syst. Sci. Discuss.: 4 September 2015

Accepted: 15 December 2015 - Published: 15 January 2016

\begin{abstract}
The responses of river runoff to shifts of largescale climatic patterns are of increasing concerns to water resource planners and managers for long-term climate change adaptation. El Niño, as one of the most dominant modes of climate variability, is closely linked to hydrologic extremes such as floods and droughts that cause great loss of lives and properties. However, the different impacts of the two types of El Niño, i.e., central Pacific (CP-) and eastern Pacific (EP)El Niño, on runoff across the conterminous US (CONUS) are not well understood. This study characterizes the impacts of the CP- and EP-El Niño on seasonal and annual runoff using observed streamflow data from 658 reference gaging stations and the NCAR-CCSM4 model. We found that surface runoff responds similarly to the two types of El Niño events in southeastern, central, southern, and western coastal regions, but differently in northeast (NE), Pacific northwest (PNW) and west north central (WNC) climatic zones. Specifically, EP-El Niño events tend to bring above-average runoff in NE, WNC, and PNW throughout the year while CP-El Niño events cause below-than normal runoff in the three regions. Similar findings were also found by analyzing NCARCCSM4 model outputs that captured both the CP- and EP-El Niño events, representing the best data set among CMIP5 models. The CCSM4 model simulates lower runoff values during CP-El Niño years than those in EP-El Niño over all of the three climatic regions (NE, PNW, and WNC) during 1950-1999. In the future (2050-2099), for both types of El Niño years, runoff is projected to increase over the NE and PNW regions, mainly due to increased precipitation $(P)$. In contrast, the increase of future evapotranspiration (ET) exceeds that of future $P$, leading to a projected decrease in
\end{abstract}

runoff over the WNC region. In addition, model analysis indicates that all of the three regions (NE, PNW, and WNC) are projected to have lower runoff in CP-El Niño years than in EP-El Niño years. Our study suggests that the US water resources may be distributed more unevenly in space and time with more frequent and intense flood and drought events. The findings from this study have important implications to water resource management at regional scales. Information generated from this study may help water resource planners to anticipate the influence of two different types of El Niño events on droughts and floods across the CONUS.

\section{Introduction}

El Niño event is a coupled ocean-atmosphere phenomenon, characterized by anomalous sea surface temperature (SST) in the equatorial Pacific Ocean, with periodicity ranging from 2 to 7 years (Trenberth, 1997). Recent studies indicate that there are two different types of El Niño events (Ashok et al., 2007; Kao and Yu, 2009; Kug et al., 2009; Larkin and Harrison, 2005a; Yeh et al., 2009): an eastern Pacific (EP) and a central Pacific (CP) type. The EP-El Niño, or the canonical El Niño, has its SST anomaly center located in the eastern equatorial Pacific (Niño 3 region), with a mean duration of about 15 months, while the CP-El Niño is characterized with anomalies of surface wind and SST confined in the central Pacific (Niño 4 region) with a mean duration of about 8 months (Kao and Yu, 2009; Mo, 2010). Because of the different convection patterns and atmospheric responses to the EP- and CP-El Niño events, the influences 
of the two types of El Niño on regional hydroclimate are different (Li et al., 2011; Mo, 2010; Yu and Zou, 2013; Yu et al., 2012). For example, the conventional EP-El Niño events caused a northeast-to-southwest, positive anomaly to negative anomaly shift in winter temperature across the US whereas the CP-El Niño events led to a northwest-tosoutheast shift pattern (Yu et al., 2012); Mo (2010) reported that the El Niño Southern Oscillation (ENSO) influence on winter $P$ over the southwest US is strengthening, while the impact on $P$ over the Ohio Valley is weakening in recent decades due to the occurrence of the CP-El Niño events. The different impacts of the two types of El Niño are not limited to the US only, but worldwide. Li et al. (2011) concluded that below-normal rainfall is found year round in northern, central, and eastern Amazon during EP-El Niño years while negative rainfall anomalies are observed in most of the Amazon during the austral summer wet season during CP-El Niño years. Kumar et al. (2006) suggested that CP-El Niño tends to produce a drought condition in India due to atmospheric subsidence. During the late 20th century, the EP-El Niño has become less common while the CP-El Niño has become more frequent (Ashok et al., 2007; Kao and Yu, 2009; Kug et al., 2009; Mo, 2010; Yeh et al., 2009). Some recent studies also suggest that the intensity of CP-El Niño events is increasing and the frequency of CP-El Niño will continue to increase in the 21st century (Kim and $\mathrm{Yu}, 2012$; Lee and McPhaden, 2010). Since ENSO is the dominant mode of climate variability (Van Oldenborgh et al., 2005; Yeh et al., 2009) and El Nino events have crucial implications to the terrestrial hydrological cycles, it is important to examine the different responses of runoff to the two types of El Niño events at regional and continental scales.

The regional distributions of runoff are largely controlled by the balances of $P$ and ET. Runoff not only is an indicator of water availability, but also plays a key role in the global biogeochemical cycle, transporting large amount of particulates and dissolved minerals as well as nutrients from land to the ocean (Boyer et al., 2006). It is well-known that climate change has great impacts on runoff and water resources worldwide (Dai et al., 2009; Déry and Wood, 2005; Gerten et al., 2008; Lettenmaier et al., 1994; Petrone et al., 2010; Piao et al., 2010; Xu et al., 2010). These climate-induced changes can, sometimes, result in diverse impacts and risks on regional hydrology and water resources (Field et al., 2014). In fact, shifts in runoff patterns have been observed in many regions (Barnett et al., 2005). For example, earlier snowmelt events are observed due to increasing temperature in winter, which will cause a shift in runoff regime from spring to late winter and thus, a runoff decrease in summer (Burn and Elnur, 2002). During the past half century, as the growing population and increasing demand for freshwater, the availability of freshwater is of great concern to water resource managers and policy-makers in a changing climate (Gleick, 2003; Milliman et al., 2008; Oki and Kanae, 2006; Vörösmarty et al., 2000; Xu et al., 2010). A better understanding

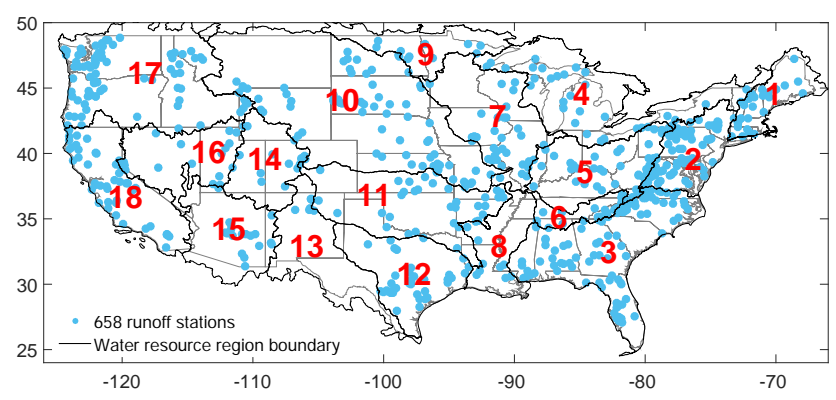

Figure 1. In all, 658 gaging stations (blue dots) and the 18 water resource regions defined by USGS over the CONUS.

on the response of runoff to the large-scale climatic patterns, especially to the climatic extremes becomes increasingly important.

Several attempts have been made to investigate the impact of El Niño on runoff over the US (Dracup and Kahya, 1994; Guetter and Georgakakos, 1996; Kahya and Dracup, 1993; Piechota et al., 1997; Twine et al., 2005; Zorn and Waylen, 1997). While these studies are informative, they either focus on only one single river basin or do not categorize the El Niño events into two types. To our best knowledge, the different impacts of two types of El Niño on runoff over the CONUS have not been carefully examined.

The overall goal of this study is to characterize the different impacts of the two types of El Niño events on regional runoff over the CONUS. We used both measured streamflow data and long-term CMIP5 modeling output to examine the spatial patterns of hydrologic response to the two different El Niño events. Section 2 describes the data and methods used in this study. In Sect. 3, we present the main results to contrast the different impacts of the two types of El Niño on runoff. Discussions and conclusions are given in Sects. 4 and 5, respectively.

\section{Data and methodology}

\subsection{Data}

In this study, monthly streamflow data (1990-2009) collected at 658 USGS gaging stations were used to examine the effects of El Niño events on watershed runoff (Fig. 1). These reference watersheds have been compiled to represent watersheds with streamflow under conditions minimally influenced by human activities (Falcone et al., 2010). Three primary criteria were used to select reference watersheds: (1) a quantitative index of anthropogenic modification within the watershed based on GIS-derived variables, (2) visual inspection of every stream gage and drainage basin from recent high-resolution imagery and topographic maps, and (3) information about man-made influences from USGS Annual Water Data Reports (Falcone et al., 2010). For detailed information, please refer to Falcone et al. (2010). Additionally, $P$ and 
ET anomalies during the two types of El Niño years are also examined; we use NOAA's precipitation reconstruction over land (PREC/L) data (Chen et al., 2002) (available at http:// www.esrl.noaa.gov/psd/data/gridded/data.precl.html), which is mainly based on rain gauge observations. ERA-Interim ET data (Uppala et al., 2008), obtained from the European Center for Medium-Range Weather Forecasts (ECMWF), is also employed (available at http://apps.ecmwf.int/datasets/). Compared with ERA-40 (Uppala et al., 2005), ERA-Interim has many improvements, particularly in the hydrologic cycle variables (Uppala et al., 2008). To improve the significance and robustness of the results from observations, the state-ofthe-art global climate models (GCMs) participating in the Coupled Model Intercomparison Project Phase 5 (CMIP5) (Taylor et al., 2012) are employed. Eight models, including NCAR-CCSM4, CNRM-CM5, GISS-E2H, GFDL-CM2.1, GFDL-ESM-2G, GFDL-ESM-2M, MPI-ESM-LR and NorESM1-M, are selected based on the studies of Mo (2010) and Kim and Yu (2012), because these model output are considered the best ones to capture both two types of El Niño in intensity and frequency. All of these models are atmospheric-ocean coupled climate models and widely used in climate community. These model outputs are downloaded from ESGF website (https://pcmdi9.1lnl.gov/projects/ esgf-1lnl/), including both historical and RCP4.5 output. All of the grid data are re-gridded into the resolution of $0.5^{\circ} \times 0.5^{\circ}$.

\subsection{Methods}

A composite method is employed in this study to highlight the common features of runoff, $P$, and ET during the EP- and CP-El Niño events. The life cycle of El Niño is based on the definition of Trenberth (1997), starting from June-July-August (JJA) to September-OctoberNovember (SON), December-January-February (DJF) and March-April-May (MAM) in the following year. The observed historical El Niño years are referred to the last column (consensus) of Table 1 in Yu et al. (2012). There are four CPEl Niño events (1991-1992, 1994-1995, 2002-2003, 20042005) and two EP-El Niño events (1997-1998, 2006-2007) during the study period. The Monte Carlo technique is used to test whether the runoff anomalies are significantly different from its climatology (Mo, 2010; Wilks, 2011).

For CMIP5 models, EP- and CP-El Niño events are defined using SST anomalies (SSTA) over the Niño 3 (150$\left.90^{\circ} \mathrm{W}, 5^{\circ} \mathrm{N}-5^{\circ} \mathrm{S}\right)$ and Niño $4\left(160^{\circ} \mathrm{E}-150^{\circ} \mathrm{W}, 5^{\circ} \mathrm{N}-5^{\circ} \mathrm{S}\right)$ regions, respectively, following Yeh et al. (2009). Specifically, if the 3-month-running mean of SSTA over Niño 3 regions is larger than $0.5^{\circ}$ for at least 5 consecutive months and also larger than that of the Niño 4 region, this year is defined as an EP-El Niño year. Conversely, if the SSTA over Niño 4 region is higher than $0.5^{\circ}$ and larger than that of Niño 3 region, the year will be defined as CP-El Niño year. (a) $\mathrm{CP}$

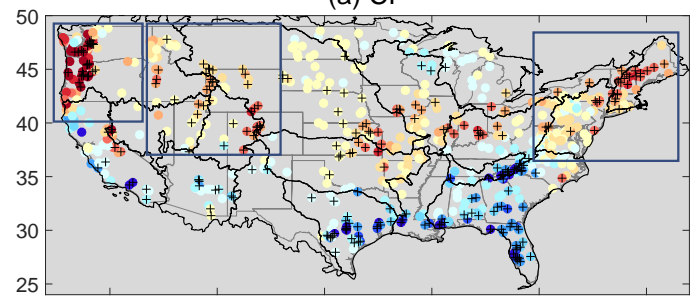

(b) $\mathrm{EP}$

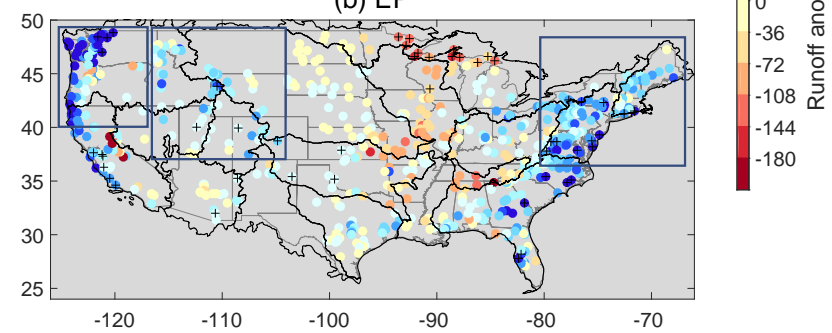

Figure 2. Composite of annual runoff anomaly (unit: $\mathrm{mm}$ ) for the two types of El Niño during the period of 1990-2009 (a) in CP-El Niño years and (b) in EP-El Niño years. + indicates results at 0.05 significance level based on a Monte Carlo test. Three climate regions (NE, PNW, and WNC, based on the climate zones of NOAA; Karl and Koss, 1984) and 18 WRRs are plotted using blue rectangles and dark black lines, respectively.

\section{Results}

\subsection{Annual runoff composite}

Figure 2 shows the composite of annual runoff anomaly during CP- and EP-El Niño years. In the CONUS, more gaging stations show negative anomalies during CP-El Niño years whereas more stations show positive anomalies during EP-El Niño years. Specifically, during CP-El Niño years (Fig. 2a), significant below-average runoff was observed in the whole northern US, with extremely dry conditions of up to $-180 \mathrm{~mm} \mathrm{yr}^{-1}$, which is roughly $-31 \%$ in NE region and $-11 \%$ in Pacific northwest (PNW) region. Aboveaverage runoff is mainly found in the southern US, with the wettest conditions of about $180 \mathrm{~mm} \mathrm{yr}^{-1}$ in the Gulf of Mexico. During EP-El Niño years (Fig. 2b), positive anomalies are scattered throughout coastal regions, such as NE, southeastern (SE), west, PNW, and western portion of the west north central (WNC) while negative anomalies are mainly observed in inland areas, especially in central and upper midwest regions. In addition, comparing Fig. 2a with Fig. 2b, we found that the responses of runoff to the two types of El Niño are similar in the SE, western, and central areas, but different in NE, PNW, and western portions of WNC, which are enclosed by dark blue rectangles in Fig. 2. We will focus on the three climate regions (Karl and Koss, 1984) that have different response signals during CP- and EP-El Niño years.

Since water resource planners are concerned with runoff variations in each water resource region (WRR) (Seaber 

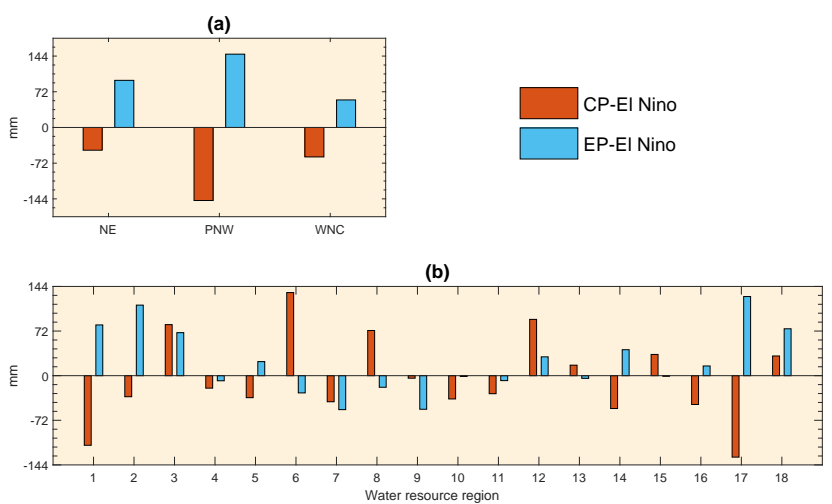

Figure 3. Domain-averaged annual runoff anomalies (unit: $\mathrm{mm}$ ) for (a) NE, PNW, and WNC climate regions; (b) the 18 WRRs, during CP- and EP-El Niño years.

et al., 1987), the responses of domain-averaged runoff to CP- and EP-El Niño events are calculated separately in the 18 WRRs, along with the domain-averaged runoff anomalies at the NE, PNW, and WNC climate zones (Fig. 3). During $\mathrm{CP}$ (EP)-El Niño years, negative (positive) runoff anomalies are observed in all of the three climatic regions (Fig. 3a). Specifically, for the NE region $\left(37-49^{\circ} \mathrm{N}, 65-80^{\circ} \mathrm{W}\right)$, the runoff anomalies are -47 and $94 \mathrm{~mm} \mathrm{yr}^{-1}$ during $\mathrm{CP}$ - and EP-El Niño years, respectively. For the PNW (40-49 N, $\left.116-125^{\circ} \mathrm{W}\right)$ and $\mathrm{WNC}\left(37-49^{\circ} \mathrm{N}, 104-116^{\circ} \mathrm{W}\right)$ regions, they are -148 and $148 \mathrm{~mm} \mathrm{yr}^{-1}$, and -61 and $54 \mathrm{~mm} \mathrm{yr}^{-1}$, respectively, during CP- and EP-El Niño years. Among the three regions, PNW has the greatest runoff anomaly values, indicating its relatively high sensitivity of annual mean discharges to El Niño events. Figure $3 b$ illustrates the runoff variations for the $18 \mathrm{WRRs}$ during CP- and EP-El Niño years. Among the $18 \mathrm{WRRs}$, eight regions have the similar responses to the two types of El Niño, i.e., WRR 3,12 , and 18 are characterized by positive anomalies, while WRR 4, 7, 9, 10, and 11, are featured with negative anomalies. There are $10 \mathrm{WRRs}$ producing different responses to the two types of El Niño, with six regions showing dry conditions in CP-El Niño and wet conditions in EP-El Niño and four regions showing the opposite response. During CP-El Niño years, 11 out of 18 WRRs $(61 \%)$ display a negative runoff anomaly compared to 9 WRRs (50\%) during EP-El Niño years. All of the WRRs in the NE, PNW, and WNC areas show dry condition in CP-El Niño years and wet condition in EP-El Niño years, including region 1, 2, 5, 14, 16, and 17. These analyses further reveal that CP-El Niño events tend to bring drier conditions than EP-El Niño events over the CONUS, in agreement with our composite results according to the NOAA climate zones (Fig. 2). It is also found that WRR regions 8,13, and 15 have positive runoff anomalies during CP-El Niño years and negative anomalies in EPEl Niño years; the different results may need further study considering the relative scarcity of the gage stations in these WRR regions.

\subsection{Seasonal composite}

El Niño usually develops in boreal summer and fall, peaks in winter, and decays in spring (Trenberth, 1997). In order to further examine the different impacts of the two types of El Niño on runoff at seasonal scales, seasonal composite analyses are also performed (Fig. 4), focusing on the three climatic zones first, followed by the 18 WRRs.

\subsubsection{NOAA climate regions}

During CP-El Niño years, significant negative runoff anomalies are found in all of the NE, PNW, and WNC climate regions throughout the year (Fig. 4, left panels). The driest condition occurs in the PNW, NE, and parts of Ohio Valley, with anomalies of up to $-45 \mathrm{~mm}$. The negative anomalies in other regions are relatively small, except for the WNC area in JJA. The dry condition is most pronounced in boreal spring (MAM). On the other hand, significant positive anomalies are mainly observed in SE in JJA. The wetter than normal conditions extend both northeastward and westward and peak in DJF and MAM. This is possibly due to high precipitation in boreal winter and spring brought by CP-El Niño (Larkin and Harrison, 2005b; Mo, 2010).

During EP-El Niño events (Fig. 4, right panels), NE, PNW, and WNC regions are characterized by positive runoff anomalies throughout the year, although NE and PNW show some exceptions (negative runoff anomalies) in DJF. The above than normal runoff can also be observed in other climate regions such as in the SE during DJF and MAM, and the west coast during DJF. The large negative anomalies are mainly restricted in the upper midwest, central, and southern US in JJA, SON, and MAM.

In summary, seasonal composite results are consistent with annual composite analyses, especially for the NE, PNW, and WNC regions, despite their peak runoff values in different seasons.

\subsubsection{WRRs}

Figure 5 illustrates the seasonal runoff responses to the two types of El Niño for the 18 WRRs. Generally speaking, the seasonal composite results are consistent with annual results (Fig. 3b). During CP-El Niño years, $67 \%$ (12 out of 18), $56 \%$ (10 out of 18 ), $50 \%$ ( 9 out of 18 ), and $56 \%$ (10 out of 18 ) of WRRs show negative runoff anomalies in JJA, SON, DJF, and MAM, respectively, indicating that the dry conditions prevail during CP-El Niño years on seasonal scales. Meanwhile, during EP-El Niño years, $56 \%$ (10 out of 18), $50 \%$ ( 9 out of 18 ), $61 \%$ (11 out of 18 ), and $44 \%$ ( 8 out of 18 ) of WRRs show positive runoff anomalies throughout the four seasons, which reveals relatively wetter conditions in EP-El Niño years. The runoff anomalies of WRRs in each season 
(a) CP-JJA

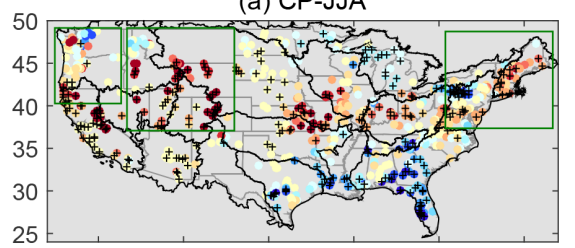

(b) CP-SON

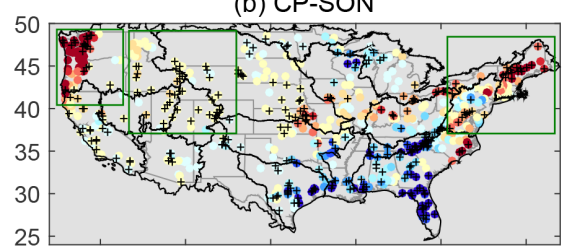

(c) CP-DJF

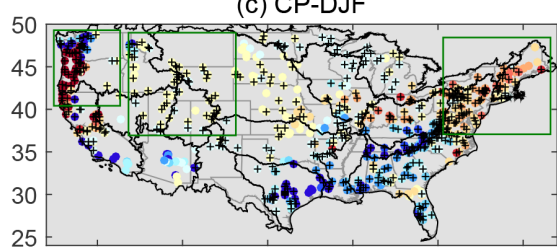

(d) CP-MAM

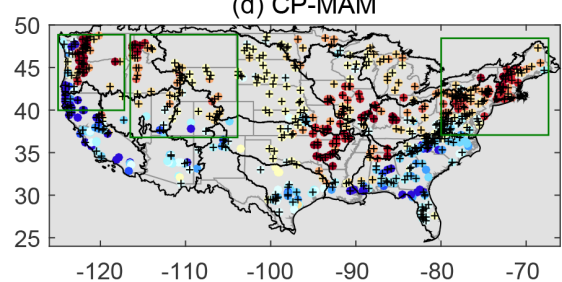

(e) EP-JJA

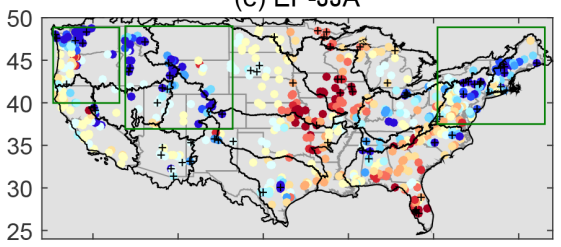

(f) EP-SON

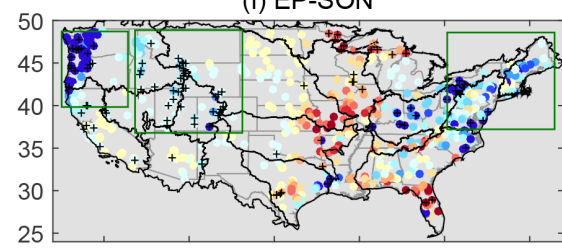

(g) EP-DJF

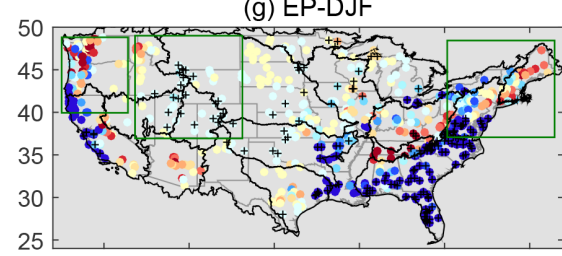

(h) EP-MAM

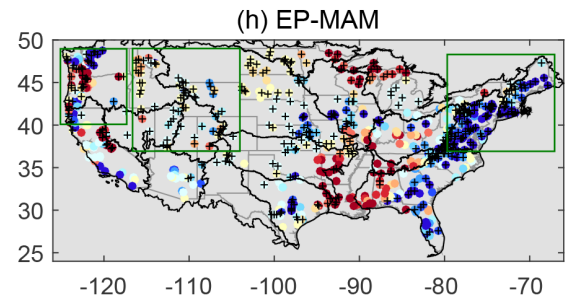

Figure 4. Seasonal composite of runoff anomaly (unit: $\mathrm{mm}$ ) for the two types of El Niño on (a) JJA, (b) SON, (c) DJF, and (d) MAM in CP-El Niño years during the period of 1990-2009; $(\mathbf{e}-\mathbf{h})$ the same as (a-d), but for EP-El Niño years. + indicates results at 0.05 significance level based on a Monte Carlo test.

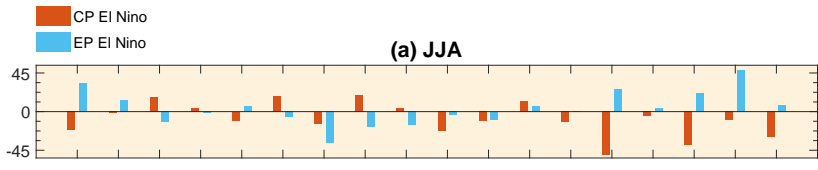

(b) SON

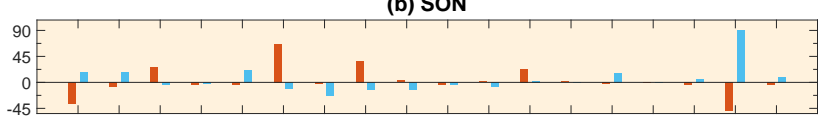

(c) DJF

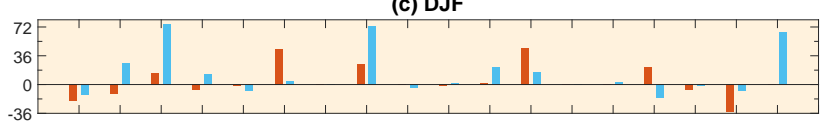

(d) MAM

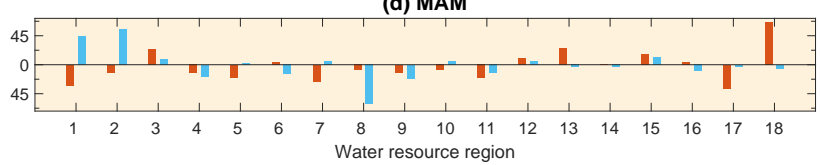

Figure 5. Seasonal domain-averaged runoff anomalies (unit: $\mathrm{mm}$ ) for the 18 WRRs at (a) JJA, (b) SON, (c) DJF, and (d) MAM during CP- and EP-El Niño years. mirror the evolution of both CP- or EP-El Niño intensities at seasonal timescales. For instance, WRR 2 has relative low runoff anomalies in boreal summer (JJA) and fall (SON) during EP-El Niño. However, the runoff anomalies are higher in winter (DJF) and peak in spring (MAM), which is consistent with the life cycle of EP-El Niño events. In conclusion, similar to the three climate regions (NE, PNW, and WNC), the 18 WRRs show the similar responses on seasonal scales as those on annual scales throughout El Niño years, despite some exceptions. For example, WRR 1, in the NE climate zone, shows negative runoff anomalies during CP-El Niño years and positive anomalies during EP-El Niño years for three seasons - JJA, SON, and MAM, but in DJF, WRR 1 shows a negative runoff anomaly. This is also the same case for WRR 5, 14, 16, and 17, although exceptions occur in different seasons.

\subsection{Modeled runoff composite}

\subsubsection{Historical}

In order to enhance the robustness of our observational results, the same composite is performed using the selected 
Table 1. Pattern correlations of runoff between the selected models and CP-/EP-El Niño years.

\begin{tabular}{lrr}
\hline & CP & EP \\
\hline NCAR-CCSM4 & 0.42 & 0.28 \\
NASA-GISS-E2H & 0.42 & 0.18 \\
CNRM-CM5 & 0.34 & -0.06 \\
GFDL-CM2.1 & 0.50 & -0.015 \\
GFDL-ESM-2G & 0.16 & 0.09 \\
GFDL-ESM-2M & 0.28 & 0.11 \\
MPI-ESM-LR & -0.21 & -0.34 \\
Nor-ESM1-M & -0.07 & -0.008 \\
\hline
\end{tabular}

CMIP5 model output, which includes more El Niño events. The El Niño years for each model were determined by the methods described in Sect. 2.2. Previous studies suggested that different identification methods may lead to slight differences in the number of El Niño years (Yu and Kim, 2013; Yu et al., 2012). Nonetheless, such differences in El Niño frequency do not affect the main results (not shown), especially when more cases are included. Pattern correlations are used to evaluate the simulation of runoff for the eight CMIP5 models, which reasonably capture the two types of El Niño (Kim and Yu, 2012; Mo, 2010). All of the eight model outputs have a pattern correlation greater than 0.8 in simulating the long-term mean monthly runoff. In simulating the response of runoff to the two types of El Niño, the NCAR-CCSM4 model is identified as the best model with the highest pattern correlation (Table 1 and Fig. 6). The main features of El Niño impacts on runoff are clearly reproduced. For example, during CP-El Niño years (Fig. 6a), the dry conditions in NE, Ohio Valley, WNC, and PNW, and wet conditions in SE, west, and southwest (SW) are simulated quite well. For EP-El Niño (Fig. 6b), the runoff anomalies are mainly characterized by wet conditions except for the Ohio Valley and some parts of PNW, consistent with observations (Fig. 2). The model results further enhanced the robustness of composite results from observations, despite some slight differences (Figs. 2 and 6). In summary, both observational results and model simulations reveal that the responses of runoff to the two types of El Niño are similar in SE, SW, and western coastal areas, but different in NE, PNW, and WNC regions.

\subsubsection{Future}

Figure 7 shows the composite of annual runoff anomaly during CP- and EP-El Niño years over 2050-2099 by using RCP4.5 output of NCAR-CCSM4 model. Consistent with conclusions based on historical runs, dominant dry (wet) conditions could also be observed during CP- (EP) El Niño years in the three climate zones (NE, PNW, and WNC) in the future. It is also found that both the intensity and the area of dry anomalies are increased during CP-El Niño years. The dry area extends from Ohio-Mississippi Valley to the

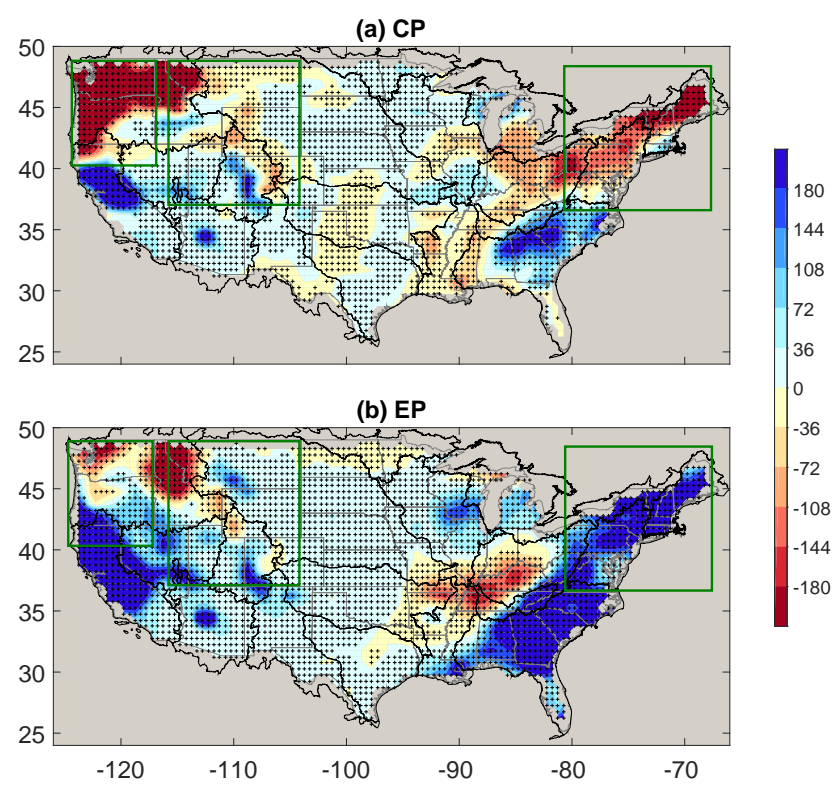

Figure 6. Same as Fig. 2, but using NCAR-CCSM4 model historical output (unit: $\mathrm{mm}$ ). + indicates results at 0.05 significance level based on a Monte Carlo test.

(a) $\mathrm{CP}$

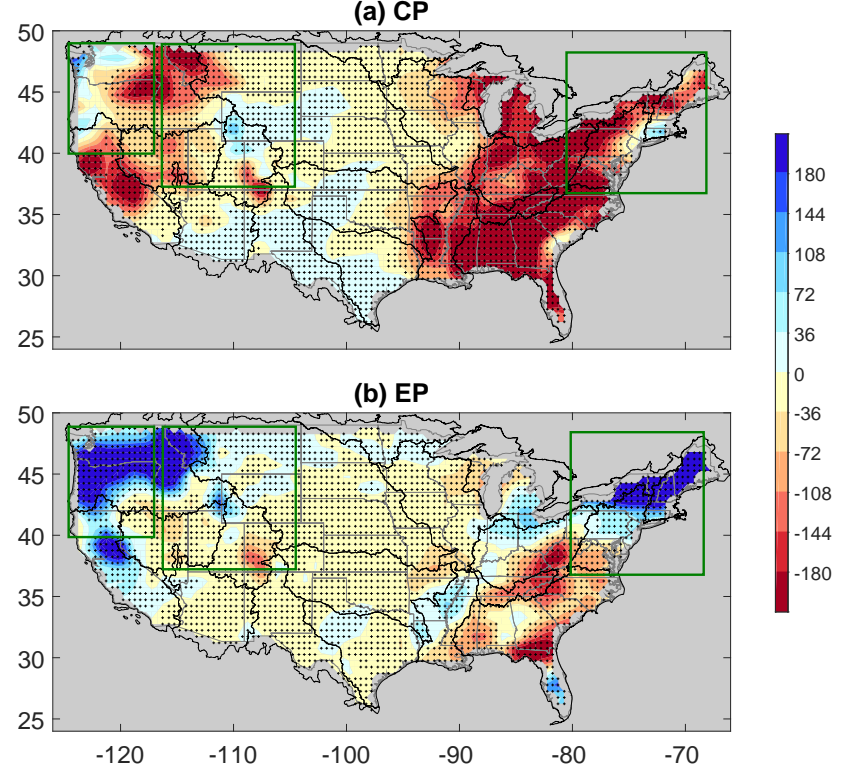

Figure 7. Same as Fig. 2, but using NCAR-CCSM4 model RCP4.5 output (unit: $\mathrm{mm}$ ). + indicates results at 0.05 significance level based on a Monte Carlo test.

whole southeastern US. This result is likely due to decreased $P$ suggested by $\mathrm{Yu}$ and Zou (2013), who found a reduction in wet area over the southeastern US associated with the southward shift of the jet streams. Compared with these areas, drying or wetting effects in other regions are relatively small, usually within $\pm 36 \mathrm{~mm} \mathrm{yr}^{-1}$. 
(a) $\mathrm{CP}$

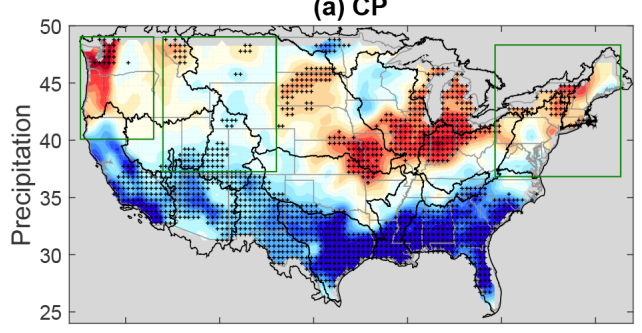

(c) $\mathrm{CP}$

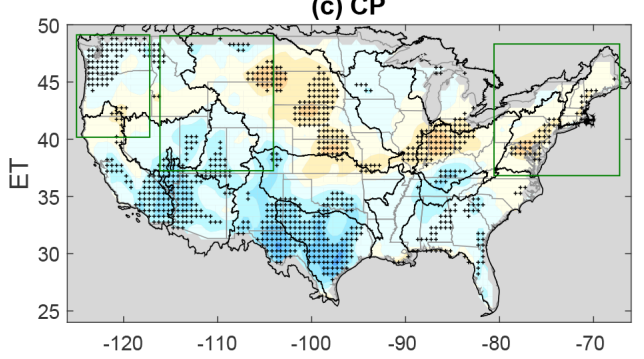

(b) EP

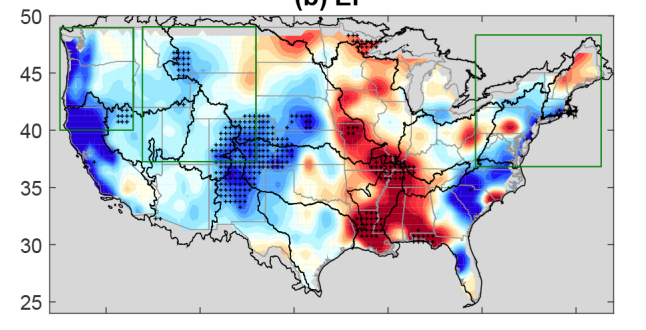

(d) EP

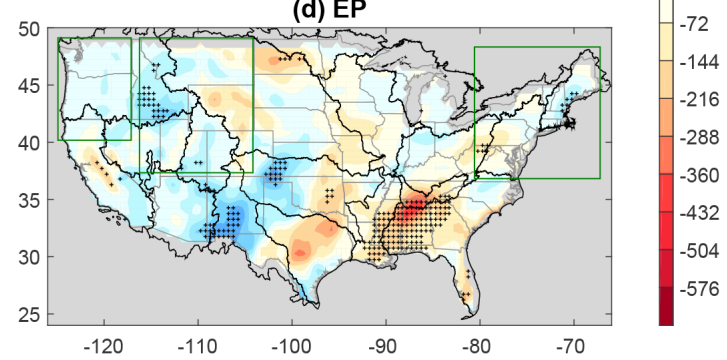

Figure 8. Same as Fig. 2, but for $P(\mathbf{a}, \mathbf{b})$ and ET $(\mathbf{c}, \mathbf{d})$ during CP- and EP-El Niño events (unit: mm). + indicates results at 0.05 significance level based on a Monte Carlo test.

Table 2. Mean annual Runoff, $P$, and ET over the three climate regions during two different types of El Niño years based on the NCARCCSM4 model historical and future simulations (unit: $\mathrm{mm}$ ).

\begin{tabular}{lrcrrrr}
\hline & \multicolumn{3}{c}{ Historical (1950-1999) } & \multicolumn{3}{c}{ RCP45 (2050-2099) } \\
\hline Northeast & Runoff & $P$ & ET & Runoff & $P$ & ET \\
\hline CP-El Niño & 418 & 1099 & 681 & 457 & 1185 & 728 \\
EP-El Niño & 494 & 1184 & 690 & 566 & 1251 & 685 \\
Climatology mean & 459 & 1135 & 676 & 505 & 1215 & 710 \\
\hline Pacific northwest & & & & & & \\
\hline CP-El Niño & 562 & 1050 & 488 & 626 & 1160 & 534 \\
EP-El Niño & 630 & 1149 & 519 & 665 & 1181 & 516 \\
Climatology mean & 611 & 1099 & 488 & 634 & 1144 & 510 \\
\hline West north central & & & & & & \\
\hline CP-El Niño & 161 & 655 & 494 & 147 & 711 & 564 \\
EP-El Niño & 168 & 705 & 537 & 163 & 733 & 570 \\
Climatology mean & 166 & 664 & 498 & 158 & 691 & 533 \\
\hline
\end{tabular}

\subsection{Water balance}

\subsubsection{Observations}

In order to further understand the response of runoff to El Niño in light of water balance, the composites of $P$ and ET are also performed (Fig. 8). For a watershed, runoff is mainly controlled by $P$ and ET (i.e., runoff $=P-$ ET) in the long term (Brubaker et al., 1993). It is shown that, over the CONUS, the runoff anomaly pattern largely follows $P$ anomaly pattern, with pattern correlations of 0.66 and 0.36 in both CP- and EP-El Niño years. For the three climate regions (NE, PNW, and $\mathrm{WNC}$ ), the $P$ anomalies are all negative dur- ing CP-El Niño years, but all positive during EP-El Niño years. The different $P$ anomalies during the two types of El Niño years largely explain the different runoff responses in the three climate regions.

\subsubsection{Model output}

Current climate data suggest that runoff variations during different El Niño years are largely determined by $P$ over the CONUS. In a warming climate, with the increase of temperature and potential ET (PET) (Dai et al., 2010; Lu et al., 2009), whether future runoff anomalies are still dominated by $P$ anomalies in the three climate regions (NE, PNW, and 
WNC) is studied by comparing NCAR-CCSM4 model historical and RCP 4.5 output (Table 2).

For the NE region, the mean annual runoff in $\mathrm{CP}$ El Niño years is about $76 \mathrm{~mm}$ lower than that in EP-El Niño years in the current climate (1950-1999) mainly because of a lower $P(1099$ vs. $1184 \mathrm{~mm})$ and nearly same ET (Table 2). In the future (2050-2099), runoff, $P$, and ET are projected to increase during both types of El Niño years in this region. However, runoff in CP-El Niño years is about $109 \mathrm{~mm}$ lower than that of future EP-El Niño years. The lower runoff is a combined effect of a lower $P(66 \mathrm{~mm})$, and a higher ET $(43 \mathrm{~mm})$ presumably due to an increase of PET as a result of global warming. Similar results are also found in the PNW region: lower runoff during CP-El Niño years than that in EP-El Niño years, an increased future runoff for both CP- and EP-El Niño events associated with increasing future $P$.

In the WNC region, similar to the NE and PNW regions, runoff is about $7 \mathrm{~mm}$ lower in CP-El Niño years than that in EP-El Niño years because $P$ is $50 \mathrm{~mm}$ lower and ET is $43 \mathrm{~mm}$ lower in the current climate (Table 2). However, when the climate warms in the future, different from the NE and PNW climate zones, surface runoff will decrease by 14 and $5 \mathrm{~mm}$ during CP- and EP-El Niño years, respectively. Table 2 indicates that the net increases of ET during the CPand EP-El Niño years, i.e., 70 and $33 \mathrm{~mm}$, are higher than the increases of $P$ (i.e., 56 and $28 \mathrm{~mm}$, respectively), leading to decreased future runoff during El Niño events over the region. Such increases of $P$ and ET in the future are possibly due to global warming. The average temperature during the two types of El Niño years increases by $\sim 2^{\circ}$ in the $21 \mathrm{st}$ century (RCP4.5), compared with the 20th century. A higher temperature usually leads to a higher PET (Dai et al., 2010; $\mathrm{Lu}$ et al., 2009). When future ET enhancement is greater than the increased $P$, such as in the WNC region during El Niño years, surface runoff will decrease.

In summary, runoff value during CP-El Niño years is lower than that during EP-El Niño years, indicating a drier condition in all three climate regions during both current and future climate. In the future when climate warms, CCSM4 model suggests that surface runoff will increase in the NE and PNW regions during the two types of El Niño, largely due to an increase of future $P$; however, over the WNC, runoff is likely to decrease because the increase of ET is much higher than $P$ increase for both El Niño events. Our analyses reveal that changes in ET due to global warming would play a more important role in altering surface discharge in some regions.

\section{Discussions}

This study reveals a more arid condition in CP-El Niño years in terms surface runoff and water balances (Fig. 2), which is mainly caused by the $P$ anomalies (Fig. 8). Over the CONUS, the three climate regions (PNW, WNC, and NE) are characterized by strong, different signals during the two different types of El Niño. The Ohio Valley is another area in- fluenced significantly by El Niño events, but shows dry condition during both CP- and EP-El Niño years (Figs. 2 and 4). Our results are in good agreement with previous results such as Weng et al. (2007, 2009), as well as Yu and Zou (2013). Yu and Zou (2013) reported a drier condition across the US in CP-El Niño years, likely due to a southward shift of the jet streams and associated winter storm activities during CP-El Niño years. Kim and Alexander (2015) also found a drier condition in PNW during CP-El Niño years by analyzing ENSO's impact on moisture transport. They concluded that during CP-El Niño, a southward shift of the cyclonic circulation over the north Pacific, which extends toward California, induces moisture transport into the $\mathrm{SW}$ region instead of PNW.

Besides large-scale circulation and associated moisture transport, other factors such as land cover/use change, topography, vegetation, and soil profile could also modify surface runoff by influencing $P$, ET, and soil water storage either directly or indirectly during different El Niño events. For example, Franczyk and Chang (2009) investigated the combined effects of climate change and land use change on the runoff of the Rock Creek basin in Oregon (part of PNW) by using both hydrological models and global climate models. They suggested that the temperature and $P$ are projected to increase by $1.2^{\circ}$ and $2 \%$ by $2040 \mathrm{~s}$, respectively, which will lead to a $2.7 \%$ increase in mean annual runoff. The annual runoff will increase by about $5 \%$ under projected climate change combined with land use change.

It is projected that the frequency of extreme El Niño events will increase due to greenhouse warming (Cai et al., 2015), which could significantly impact global weather patterns, ecosystems, agriculture, drought, floods, and other extreme events (Aronson et al., 2000; Cai et al., 2014; Vos et al., 1999). Yeh et al. (2009) showed that climate change will increase the frequency of the CP-El Niño compared to the EPEl Niño by using CMIP3 climate models. Kim and Yu (2012) reported that the intensity of CP-El Niño increases steadily from the pre-industrial to the historical and the RCP4.5 simulations in the CMIP5 climate models. As the CP-El Niño will occur more frequently, our runoff results shown here suggest that the drought will be intensified in the future. This finding delivers informative socio-economic implications and will benefit our management and policy-decision of water resources to reduce the damage of flood and drought in the future.

Two limitations still exist in our study. First, the observed runoff data only have a length of 20 years, which covers a limited number of El Niño events. We noticed that ENSO has variations on multidecadal timescale (Brown and Comrie, 2004; Cai et al., 2010; Dong et al., 2006; Mo, 2010). For instance, Mo (2010) compared the impact of ENSO on temperature and precipitation in the continental US for the periods of 1915-1960 and 1961-2006, and reported discernible changes between the two time periods on seasonal scale. The observed runoff response to the two types of El Niño events 
needs further validation when longer observational data are available. Second, our results only characterized the impact of El Niño on natural runoff without considering local factors especially land use and land cover change (LULC). For those gages with LULC, El Niño also plays a role in the variability of runoff. However, the relative contributions of climate change and human activities such as LULC need further study, possibly by using modeling studies, which is the next step in our research.

\section{Conclusions}

The different impacts of CP- and EP-El Niño events on surface runoff over the CONUS were studied using 658 gaging stations and NCAR-CCSM4 model output. It is shown that surface runoff responds similarly to the two types of El Niño events in southeastern, central, southern, and western coastal regions, but differently in NE, PNW, and WNC states. In general, the CP-El Niño events are likely to cause drier conditions with lower runoff whereas the EP-El Niño events tend to result in wetter than normal conditions over the CONUS. This can also be seen from the runoff responses at the 18 WRRs. Such runoff anomalies are largely following the variation of $P$ during El Niño years. The NCAR-CCSM4 model outputs further support the conclusions derived from observations, i.e., a drier condition over the CONUS during CP-El Niño years than EP-El Niño. It is also projected that future runoff tends to decrease over the WNC region, but to increase over the NW and PNE regions during both types of El Niño events as a result of the changes in the balances between $P$ and ET. We conclude that surface water resources may be distributed more unevenly in space and time in the future El Niño years. Such information is useful to develop plans in anticipating hydrologic extremes under climate change.

Acknowledgements. We would like to thank USGS for providing runoff data, NOAA for providing land precipitation data, and ECMWF for providing ERA ET data, as well as ESGF portal for providing CMIP5 global climate model output. We also thank the two anonymous reviewers and M. Budde, as well as R. Tilburg for their helpful comments on earlier version of this manuscript. This study is supported by the National Science Foundation grant AGS-1147608, and US Department of Agriculture grant 2014-67003-22068.

Edited by: L. Samaniego

\section{References}

Aronson, R. B., Precht, W. F., Macintyre, I. G., and Murdoch, T. J.: Ecosystems: Coral bleach-out in Belize, Nature, 405, 36-36, doi:10.1038/35011132, 2000.
Ashok, K., Behera, S. K., Rao, S. A., Weng, H., and Yamagata, T.: El Niño Modoki and its possible teleconnection, J. Geophys Res.-Oceans (1978-2012), 112, C11007, doi:10.1029/2006JC003798, 2007.

Barnett, T. P., Adam, J. C., and Lettenmaier, D. P.: Potential impacts of a warming climate on water availability in snow-dominated regions, Nature, 438, 303-309, doi:10.1038/nature04141, 2005.

Boyer, E. W., Howarth, R. W., Galloway, J. N., Dentener, F. J., Green, P. A., and Vörösmarty, C. J.: Riverine nitrogen export from the continents to the coastsm, Global Biogeochem. Cy., 20, GB1S91, doi:10.1029/2005GB002537, 2006.

Brown, D. P. and Comrie, A. C.: A winter precipitation "dipole" in the western United States associated with multidecadal ENSO variability, Geophys. Res. Lett., 31, L09203, doi:10.1029/2003GL018726, 2004.

Brubaker, K. L., Entekhabi, D., and Eagleson, P.: Estimation of continental precipitation recycling, J. Climate, 6, 1077-1089, doi:10.1175/1520-0442(1993)006<1077:EOCPR>2.0.CO;2, 1993.

Burn, D. H. and Elnur, M. A. H.: Detection of hydrologic trends and variability, J. Hydrol., 255, 107-122, doi:10.1016/S00221694(01)00514-5, 2002.

Cai, W., Van Rensch, P., Cowan, T., and Sullivan, A.: Asymmetry in ENSO teleconnection with regional rainfall, its multidecadal variability, and impact, J. Climate, 23, 4944-4955. doi:10.1175/2010JCLI3501.1, 2010.

Cai, W., Borlace, S., Lengaigne, M., Van Rensch, P., Collins, M., Vecchi, G., Timmermann, A., Santoso, A., McPhaden, M. J., Wu, L., England, M. H., Wang, G., Guilyardi, E., and Jin, F. : Increasing frequency of extreme El Niño events due to greenhouse warming, Nature Climate Change, 4, 111-116, doi:10.1038/nclimate2100, 2014.

Cai, W., Santoso, A., Wang, G., Yeh, S.-W., An, S.-I., Cobb, K. M., Collins, M., Guilyardi, E., Jin, F., Kug, J. S., Lengaigne, M., McPhaden, M. J., Takahashi, K., Timmermann, A., Vecchi, G., Watanabe, M., and Wu, L.: ENSO and greenhouse warming, Nature Climate Change, doi:10.1038/nclimate2743, 2015.

Chen, M., Xie, P., Janowiak, J. E., and Arkin, P. A.: Global land precipitation: A 50-yr monthly analysis based on gauge observations, J. Hydrometeorol., 3, 249-266, doi:10.1175/15257541(2002)003<0249:GLPAYM>2.0.CO;2, 2002.

Dai, A., Qian, T., Trenberth, K. E., and Milliman, J. D.: Changes in continental freshwater discharge from 1948 to 2004, J. Climate, 22, 2773-2792, doi:10.1175/2008JCLI2592.1, 2009.

Dai, Z., Trettin, C. C., Li, C., Amatya, D. M., Sun, G., and Li, H.: Sensitivity of Stream flow and Water Table Depth to Potential Climatic Variability in a Coastal Forested Watershed, J. Am. Water Resour. As., 46, 1036-1048, doi:10.1111/j.17521688.2010.00474.x, 2010.

Déry, S. J. and Wood, E.: Decreasing river discharge in northern Canada, Geophys. Res. Lett., 32, L10401, doi:10.1029/2005GL022845, 2005.

Dong, B., Sutton, R. T., and Scaife, A. A.: Multidecadal modulation of El Nino-Southern Oscillation (ENSO) variance by Atlantic Ocean sea surface temperatures, Geophys. Res. Lett., 33, L08705, doi:10.1029/2006GL025766, 2006.

Dracup, J. A. and Kahya, E. The relationships between US streamflow and La Niña events, Water Resour. Res., 30, 2133-2141, doi:10.1029/94WR00751, 1994. 
Falcone, J. A., Carlisle, D. M., Wolock, D. M., and Meador, M. R.: GAGES: a stream gage database for evaluating natural and altered flow conditions in the conterminous United States, Ecology, 91, 621-621, doi:10.1890/09-0889.1, 2010.

Field, C., Barros, V., Dokken, D., Mach, K., Mastrandrea, M., Bilir, T., Chatterjee, M., Ebi, K., Estrada, Y. O., Genova, R. C., Girma, B., Kissel, E. S., Levy, A. N., MacCracken, S., Mastrandrea, P. R., and White, L. L.: IPCC, 2014: Climate Change 2014: Impacts, Adaptation, and Vulnerability. Part A: Global and Sectoral Aspects. Contribution of Working Group II to the Fifth Assessment Report of the Intergovernmental Panel on Climate Change: Cambridge University Press, Cambridge, UK and New York, NY, USA, 2014.

Franczyk, J. and Chang, H.: The effects of climate change and urbanization on the runoff of the Rock Creek basin in the Portland metropolitan area, Oregon, USA, Hydrol. Process., 23, 805-815. doi:10.1002/hyp.7176, 2009.

Gerten, D., Rost, S., von Bloh, W., and Lucht, W.: Causes of change in 20th century global river discharge, Geophys. Res. Lett., 35, L20405, doi:10.1029/2008GL035258, 2008.

Gleick, P. H.: Global freshwater resources: soft-path solutions for the 21st century, Science, 302, 1524-1528, doi:10.1126/science.1089967, 2003.

Guetter, A. K. and Georgakakos, K. P.: Are the El Niño and La Niña predictors of the Iowa River seasonal flow?, J. Appl. Meteorol., 35, 690-705, doi:10.1175/15200450(1996)035<0690:ATENAL>2.0.CO;2, 1996.

Kahya, E. and Dracup, J. A.: US streamflow patterns in relation to the El Niño/Southern Oscillation, Water Resour. Res., 29, 24912503, doi:10.1029/93WR00744, 1993.

Kao, H.-Y. and Yu, J.-Y.: Contrasting eastern-Pacific and central-Pacific types of ENSO, J. Climate, 22, 615-632, doi:10.1175/2008JCLI2309.1, 2009.

Karl, T. and Koss, W. J.: Regional and National Monthly, Seasonal, and Annual Temperature Weighted by Area, 1895-1983, National Climatic Data Center, Asheville, NC, USA, 1984.

Kim, H.-M. and Alexander, M. A.: ENSO's Modulation of Water Vapor Transport over the Pacific North America Region, J. Climate, 28, 3846-3856, doi:10.1175/JCLI-D-14-00725.1, 2015.

Kim, S. T. and Yu, J. Y.: The two types of ENSO in CMIP5 models, Geophys. Res. Lett., 39, L11704, doi:10.1029/2012GL052006, 2012.

Kug, J.-S., Jin, F.-F., and An, S.-I.: Two types of El Niño events: cold tongue El Niño and warm pool El Niño, J. Climate, 22, 1499-1515. doi:10.1175/2008JCLI2624.1, 2009.

Kumar, K. K., Rajagopalan, B., Hoerling, M., Bates, G., and Cane, M.: Unraveling the mystery of Indian monsoon failure during El Nino, Science, 314, 115-119, doi:10.1126/science.1131152, 2006.

Larkin, N. K. and Harrison, D.: Global seasonal temperature and precipitation anomalies during El Niño autumn and winter, Geophys. Res. Lett., 32, L16705, doi:10.1029/2005GL022860, 2005a.

Larkin, N. K. and Harrison, D.: On the definition of El Niño and associated seasonal average US weather anomalies, Geophys. Res. Lett., 32, L13705, doi:10.1029/2005GL022738, 2005 b.

Lee, T. and McPhaden, M. J.: Increasing intensity of El Niño in the central-equatorial Pacific, Geophys. Res. Lett., 37, L14603, doi:10.1029/2010GL044007, 2010.
Lettenmaier, D. P., Wood, E. F., and Wallis, J. R.: Hydroclimatological trends in the continental United States, 1948-88, J. Climate, 7, 586-607, doi:10.1175/15200442(1994)007<0586:HCTITC>2.0.CO;2, 1994.

Li, W., Zhang, P., Ye, J., Li, L., and Baker, P. A.: Impact of two different types of El Niño events on the Amazon climate and ecosystem productivity, J. Plant Ecol-UK, 4, 91-99, doi:10.1093/jpe/rtq039, 2011.

Lu, J., Sun, G., McNulty, S. G., and Comerford, N. B. Sensitivity of pine flatwoods hydrology to climate change and forest management in Florida, USA, Wetlands, 29, 826-836, doi:10.1672/07162.1, 2009.

Milliman, J., Farnsworth, K., Jones, P., Xu, K., and Smith, L.: Climatic and anthropogenic factors affecting river discharge to the global ocean, 1951-2000, Global Planet. Change, 62, 187-194, doi:10.1016/j.gloplacha.2008.03.001, 2008.

Mo, K. C.: Interdecadal modulation of the impact of ENSO on precipitation and temperature over the United States, J. Climate, 23, 3639-3656, doi:10.1175/2010JCLI3553.1, 2010.

Oki, T. and Kanae, S.: Global hydrological cycles and world water resources, Science, 313, 1068-1072, doi:10.1126/science.1128845, 2006.

Petrone, K. C., Hughes, J. D., Van Niel, T. G., and Silberstein, R. P.: Streamflow decline in southwestern Australia, 1950-2008, Geophys. Res. Lett., 37, L11401, doi:10.1029/2010GL043102, 2010.

Piao, S., Ciais, P., Huang, Y., Shen, Z., Peng, S., Li, J., Zhou, L., Liu, H., Ma, Y., Ding, Y., Friedlingstein, P., Liu, C., Tan, K., Yu, Y., Zhang, T., and Fang, J.: The impacts of climate change on water resources and agriculture in China, Nature, 467, 43-51, doi:10.1038/nature09364, 2010.

Piechota, T. C., Dracup, J. A., and Fovell, R. G.: Western US streamflow and atmospheric circulation patterns during El Niño-Southern Oscillation, J. Hydrol., 201, 249-271, doi:10.1016/S0022-1694(97)00043-7, 1997.

Seaber, P. R., Kapinos, F. P., and Knapp, G. L.: Hydrologic unit maps: US Government Printing Office, Washington, DC, USA, 20401, 1987.

Taylor, K. E., Stouffer, R. J., and Meehl, G. A.: An overview of CMIP5 and the experiment design, B. Am. Meteorol. Soc., 93, 485-498, doi:10.1175/BAMS-D-11-00094.1, 2012.

Trenberth, K. E.: The definition of El Nino, B. Am. Meteorol. Soc., 78, 2771-2777, doi:10.1175/15200477(1997)078<2771:TDOENO>2.0.CO;2, 1997.

Twine, T. E., Kucharik, C. J., and Foley, J. A. Effects of El NinoSouthern Oscillation on the climate, water balance, and streamflow of the Mississippi River basin, J. Climate, 18, 4840-4861, doi:10.1175/JCLI3566.1, 2005.

Uppala, S., Dee, D., Kobayashi, S., Berrisford, P., and Simmons, A.: Towards a climate data assimilation system: status update of ERA-Interim, ECMWF newsletter, 115, 12-18, 2008.

Uppala, S. M., Kållberg, P., Simmons, A., Andrae, U., Bechtold, V., Fiorino, M., Gibson, J., Haseler, J., Hernandez, A., Kelly, G. A., Li, X., Onogi, K., Saarinen, S., Sokka, N., Allan, R. P., Andersson, E., Arpe, K., Balmaseda, M. A., Beljaars, A. C. M., Berg, L. V., Bidlot, J., Bormann, N., Caires, S., Chevallier, F., Dethof, A., Dragosavac, M., Fisher, M., Fuentes, M., Hagemann, S., Hólm, E., Hoskins, B. J., Isaksen, L., Janssen, P. A. E. M., Jenne, R., McNally, A. P., Mahfouf, J. F., Morcrette, J. J., Rayner, N. A., Saunders, R. W., Simon, P., Sterl, A., Trenberth, 
K. E., Untch, A., Vasiljevic, D., Viterbo, P., and Woollen, J.: The ERA-40 re-analysis, Q. J. Roy. Meteor. Soc., 131, 2961-3012, doi:10.1256/qj.04.176, 2005.

van Oldenborgh, G. J., Philip, S. Y., and Collins, M: El Niño in a changing climate: a multi-model study, Ocean Sci., 1, 81-95, doi:10.5194/os-1-81-2005, 2005.

Vörösmarty, C. J., Green, P., Salisbury, J., and Lammers, R. B.: Global water resources: vulnerability from climate change and population growth, Science, 289, 284-288, doi:10.1126/science.289.5477.284, 2000.

Vos, R., Velasco, M., and Labastida, E.: Economic and social effects of "El Niño" in Ecuador, 1997-8, ISS Working Paper Series/General Series, 292, 1-55, 1999.

Weng, H., Ashok, K., Behera, S. K., Rao, S. A., and Yamagata, T. Impacts of recent El Niño Modoki on dry/wet conditions in the Pacific rim during boreal summer, Clim. Dynam., 29, 113-129, doi:10.1007/s00382-007-0234-0, 2007.

Weng, H., Behera, S. K., and Yamagata, T.: Anomalous winter climate conditions in the Pacific rim during recent El Niño Modoki and El Niño events, Clim. Dynam., 32, 663-674, doi:10.1007/s00382-008-0394-6, 2009.

Wilks, D. S.: Statistical methods in the atmospheric sciences, 3rd ed., Vol. 100, Academic press, Waltham, MA, USA, 2011.
Xu, K., Milliman, J. D., and Xu, H. Temporal trend of precipitation and runoff in major Chinese Rivers since 1951, Global Planet. Change, 73, 219-232, doi:10.1016/j.gloplacha.2010.07.002, 2010.

Yeh, S.-W., Kug, J.-S., Dewitte, B., Kwon, M.-H., Kirtman, B. P., and Jin, F.-F.: El Niño in a changing climate, Nature, 461, 511514, doi:10.1038/nature08316, 2009.

$\mathrm{Yu}$, J. Y. and Kim, S. T.: Identifying the types of major El Niño events since 1870, Int. J. Climatol., 33, 2105-2112, doi:10.1002/joc.3575, 2013.

Yu, J.-Y. and Zou, Y.: The enhanced drying effect of CentralPacific El Niño on US winter, Environ. Res. Lett., 8, 014019, doi:10.1088/1748-9326/8/1/014019, 2013.

Yu, J. Y., Zou, Y., Kim, S. T., and Lee, T.: The changing impact of El Niño on US winter temperatures, Geophys. Res. Lett., 39, L15702, doi:10.1029/2012GL052483, 2012.

Zorn, M. R. and Waylen, P. R. Seasonal response of mean monthly streamflow to El Nino/Southern Oscillation in north central Florida, The Professional Geographer, 49, 51-62, doi:10.1111/0033-0124.00055, 1997. 